Article

\title{
Development and Quality Evaluation of Ready to Serve (RTS) Beverage from Cape Gooseberry (Physalis peruviana L.)
}

\author{
R. Hemalatha, Amarjeet Kumar, Om Prakash, A. Supriya, A. S. Chauhan ${ }^{(D)}$ \\ and V. B. Kudachikar * (D) \\ Fruit and Vegetable Technology Department, CSIR-Central Food Technological Research Institute, \\ Mysore 570020, India; rbkud@yahoo.com (R.H.); amarjeetkumar011@gmail.com (A.K.); \\ jangidomi007@gmail.com (O.P.); asupriya2810@yahoo.com (A.S.); attar2010@yahoo.com (A.S.C.) \\ * Correspondence: vbkudachikar@cftri.res.in; Tel: +91-821-251-5653
}

Received: 9 April 2018; Accepted: 30 May 2018; Published: 5 June 2018

\begin{abstract}
This study aimed to develop a process for the development of ready to serve (RTS) beverages from enzyme liquefied (pectinase) Cape gooseberry juice with additives and preservatives. Storage stability of the RTS beverage at both refrigerated temperature (LT: $4 \pm 1{ }^{\circ} \mathrm{C}$ ) and room temperature (RT: $27 \pm 2{ }^{\circ} \mathrm{C}$ ) were evaluated for 90 days for microbial, sensorial and physicochemical quality parameters. The stability of RTS beverage stored at LT $\left(4 \pm 1{ }^{\circ} \mathrm{C}\right)$ was excellent with a retention of the primary quality attributes ascorbic acid $(15.44 \mathrm{mg} / 100 \mathrm{~mL})$, total phenolic content (15.50 mg GAE $/ 100 \mathrm{~mL})$, total carotene $(1.07 \mathrm{mg} / 100 \mathrm{~mL}), \beta$-carotene $(0.78 \mathrm{mg} / 100 \mathrm{~mL})$, high viscosity (30.29 cp), and with high sensory scores of the product (8.3) up to 90 days as compared to the overall acceptability (6.5) of RT stored RTS for 60 days. Additionally, both the LT and RT stored RTS beverages had microbial counts within the permissible limits. Therefore, both beverages were safe to consume at the end of storage duration. In conclusion, the RTS beverage developed from Cape gooseberry could be served as functional health drink alternative to synthetic soft drinks due to its unique features (high nutritive values, high organoleptic values and high stability) of the product.
\end{abstract}

Keywords: cape gooseberry juice; RTS beverage; ascorbic acid; $\beta$-carotene; sensory profile; microbiological profile; storage conditions

\section{Introduction}

In tropical and subtropical regions, more than 500 edible fruits are cultivated every year; however, only less than 15 are commercially processed. Considering the tremendous demand for tropical fruit processed products in the International markets, during the last decades the processing of tropical fruits began in many countries. As these fruits are highly seasonal and perishable, thus their seasonal surpluses in different regions are wasted in bulk due to improper handling, distribution, marketing, and inadequate storage facilities. For this reason, fruits in excess need immediate processing for value-added products to minimize postharvest losses, which are about $30-35 \%$ according to National Horticultural Board [1]. The Cape gooseberry is increasingly becoming an important crop in functional food production and is of economic importance [2]. Although golden berries are mainly consumed fresh, they are also utilized in making sauces, syrups, and marmalades [3], or dehydrated products as raisins for bakery products. They are also used in cocktails, snacks, chocolate-covered candies, jam, jellies, and cereal breakfast. The juice is rich in fat-soluble bioactive compounds (such as tocopherols and phytosterols) and could be a novel source of functional drinks [4], such as pomace $[2,5,6]$. Fruit juices and beverages are mainly processed food products that are 
conveniently used and liked by all age group consumers. They also provide a better chance of meeting the daily requirement of nutrients in a healthy diet [7]. There are many different product variants marketed in India, such as sweetened carbonated soft drinks, clarified juice beverages, pulpy beverages, and soda water. Among these non-alcoholic beverages, the share of fruit juice based beverages is presently very small as compared to synthetic carbonated beverages [7]. Consumers are now gradually shifting towards the consumption of natural fruit juice based beverages because of their quality, high nutritional content, medicinal importance, and good calorific value over synthetic beverages [7].The advantage of a ready to serve (RTS) beverage is that there is no need to dilute it further with a required quantity of water, unlike other concentrated beverages such as squash, or syrup, which are diluted judiciously with water before consumption. At present, the Cape gooseberry is an underutilized fruit in India and has a limited shelf life in fresh form. Eventually, there is the need for processing it into a value-added product like an RTS beverage with extended storage life so that the product can be consumed throughout the year and consumers may relish its unique taste and flavor and quench their thirst. The demand for natural fruit juice based beverages with high nutritional value and other health-imparting attributes are immense in the global market. Fruit berries are considered an important fruit with unique bioactive compounds. Berries can provide health benefits because of their high amounts of antioxidants, vitamins, minerals, and fiber content [8]. The Cape gooseberry (Physalis peruviana L.) is a plant native to South America with an underutilized berry-like fruit that belongs to the family Solanaceae. South America is the origin of the fruit. Its cultivation spread across the globe and includes several tropical and sub-tropical countries, including countries of North and South Africa, India, Australia, New Zealand, Venezuela, Colombia, Chile, and Peru [9-11]. It is an herbaceous, short-lived, annual plant bearing fruit berries with an average fruit berry weight of 4-10 g. Individual fruit berries are covered by a bright yellow peel and are also protected by an enlarged calyx. The fruit berry yield is 300 berries per plant and fruit productivity is around 20 to 33 Tons/hectare. It shares a little similarity with tomato in flavor and appearance, combining both the tastes of sweet and sour $[4,12,13]$. It is commonly known as the golden berry in western countries, primarily in English speaking countries. It is also well known by several other names in the World, such as uchuva in Colombia, the Cape gooseberry in South Africa, rasbhari in India, uvilla in Ecuador, and aguaymanto in Peru, etc. [14]. The accepted name of the species is the genus Physalis (Family Solanaceae). Six species of Physalis are cultivated in India, examples include P. alkekengi (L.), P. angulata (L.), P. ixocarpa Brot. Ex. Hornem, P. longifolia (Nutt.), P. peruviana (L.), and the last species P. minima (L.), which is commonly known as a weed [15]. The Cape gooseberry is well-known for its organoleptic properties with special reference to its unique flavor and color. The berry is bestowed with several polyunsaturated fatty acids, carbohydrates, vitamins (A, B, C, E, and $\mathrm{K}$ ), phytosterols, essential minerals (phosphorus, iron, potassium, and zinc), physalin compound, pectin, polyphenols, carotenoids, melatonin, and withanolides [16-19]. Many medicinal 'properties are recognized in Physalis' such as antispasmodic, diuretic, antiseptic, sedative, analgesic, and other health benefits include the berry's ability to fortify the optic nerve of the eyes, throat trouble relief, and the elimination of intestinal parasites, amoeba and albumin from the kidneys [20]. It has also been used to cure cancer, leukemia, malaria, asthma, hepatitis, dermatitis, and rheumatism [21]. Epidemiological studies revealed that increased consumption of the Cape gooseberry could lead to a lower risk of chronic degenerative diseases [22]. The fruit contains $15 \%$ soluble solids of mainly sugars, and its high level of fructose makes it suitable for a diabetic patient [23]. Studies revealed that eating the fruit of Physalis can reduce the blood glucose level in young adults after $90 \mathrm{~min}$ postprandial, causing a marked hypoglycemic effect after this period [3].

The present study was focused with an objective to optimize process conditions for the preparation of a RTS beverage from pectinase liquefied Cape gooseberry (Physalis peruviana L.) fruit berry juice and to evaluate the quality attributes of the formulated RTS beverage, such as the microbiological, sensorial, and physicochemical changes of the formulated RTS beverage, during storage under different storage (LT-Refrigerated Temperature and RT-Room Temperature) conditions. 


\section{Materials and Methods}

\subsection{Materials}

\subsubsection{Chemicals}

All chemicals and reagents used in the experiments were of analytical grade and purchased mostly from SD Fine, India, Fisher Scientific, Mumbai, Maharashtra, India, Sigma Aldrich, India and Himedia, Mumbai, India.

\subsubsection{Sample Collection}

The fully ripened Cape gooseberry fruits were procured from Allahabad, Uttar Pradesh and transported to the laboratory in corrugated fiber boxes and kept in cold room for 10-12 h to remove the field heat and adhering dirt. The calyx was removed from the fruit, washed, air dried, and then pulped using a mechanical pulper. The pulp was packed in low-density polyethylene (LDPE) bags and stored at $-20{ }^{\circ} \mathrm{C}$ till further beverage preparation and analysis.

\subsection{Methods}

\subsubsection{Pulp Homogenization and Enzyme Liquefaction}

The pulp was homogenized in a blender (Model: JM60B, Serial No:504031, JM Series Colloid Miller, Zhengzhou, China) and pectinase enzyme treatment was given for better smooth juice extraction and better yield recovery as previously reported [24]. Briefly, 1\% pectinase enzyme was added to the homogenized pulp of Cape gooseberry with thorough stirring. After that it was incubated at room temperature for two hours after covering the container with a muslin cloth. Intermittently, stirring of the enzyme-treated homogenized pulp was done to allow enzymatic liquefaction to complete the process. After completion of the two-hour incubation at RT, the enzyme liquefied pulp was heated to $70{ }^{\circ} \mathrm{C}$ for $5 \mathrm{~min}$ to inactivate the added enzyme after that the pulp was cooled to RT and strained through two layers of muslin cloth to facilitate smooth juice extraction. This juice yield was $70 \%$, used for beverage preparation and analysis.

\subsubsection{Preparation of RTS Beverage Formulation}

The RTS beverage was formulated as per the flowchart illustrated in Figure 1 with $10 \%(w / w)$ enzyme liquefied Cape gooseberry juice. Both the TSS and the acidity of native juice was determined and subtracted from the required quantity of the citric acid and sugar added to the required quantity of water for syrup preparation. Finally adjusted the TSS to $10^{\circ}$ Brix and the acidity to $0.3 \%$. After that it was filtered and $10 \%$ enzyme liquefied cap gooseberry juice and emulsifier $(0.15 \%(w / w)$ low methoxy pectin (LMP, SRL, Mumbai, India) was added to it as per the batch size requirement, it then proceeded to pasteurization at $90^{\circ} \mathrm{C}$ for a holding time of $1 \mathrm{~min}$. The pasteurized RTS beverage was cooled down to $70{ }^{\circ} \mathrm{C}$ then sodium benzoate $(120 \mathrm{ppm})$ as a preservative was added with thorough stirring and immediately hot filled within $70{ }^{\circ} \mathrm{C}$ temperature in previously sterilized PET bottles (100 mL capacity) and then capped with hot water sterilized lids to ensure the safety of the prepared RTS beverage. The bottled RTS beverages kept in packaged form for storage at two different varying temperatures, namely refrigerated temperature (LT: $4 \pm 1^{\circ} \mathrm{C}$ ) and room temperature (RT: $27 \pm 2{ }^{\circ} \mathrm{C}$ ), after that the quality of the stored RTS beverages was periodically monitored at regular intervals.

\subsection{Storage Stability and Shelf-Life Extension Studies}

The samples were prepared from the enzyme liquefied juice of the Cape gooseberry. They were then packaged in PET bottles, stored both at refrigerated temperature (LT: $4 \pm 1^{\circ} \mathrm{C}$ ) as well as room temperature (RT: $27 \pm 2{ }^{\circ} \mathrm{C}$ ) conditions for the evaluation of shelf life stability regarding microbiological safety, sensory acceptance, and physicochemical changes. 


\subsubsection{Physicochemical Analysis}

Color

The color measurement of various RTS beverage samples was carried out in triplicate using a colorimeter (Shimadzu, Model: UV 2100, Kyoto, Japan) at the wavelength ranging from 400 to $700 \mathrm{~nm}$ and measured as Hunter color $\left(\mathrm{L}^{*}, \mathrm{a}^{*}\right.$ and $\left.\mathrm{b}^{*}\right)$ values [25]. Where, $\mathrm{L}^{*}$ indicates luminosity or brightness, $\mathrm{a}^{*}$ corresponds to greenness $(-) /$ redness $(+)$, and $b^{*}$ corresponds to blueness $(-)$ /yellowness $(+)$.

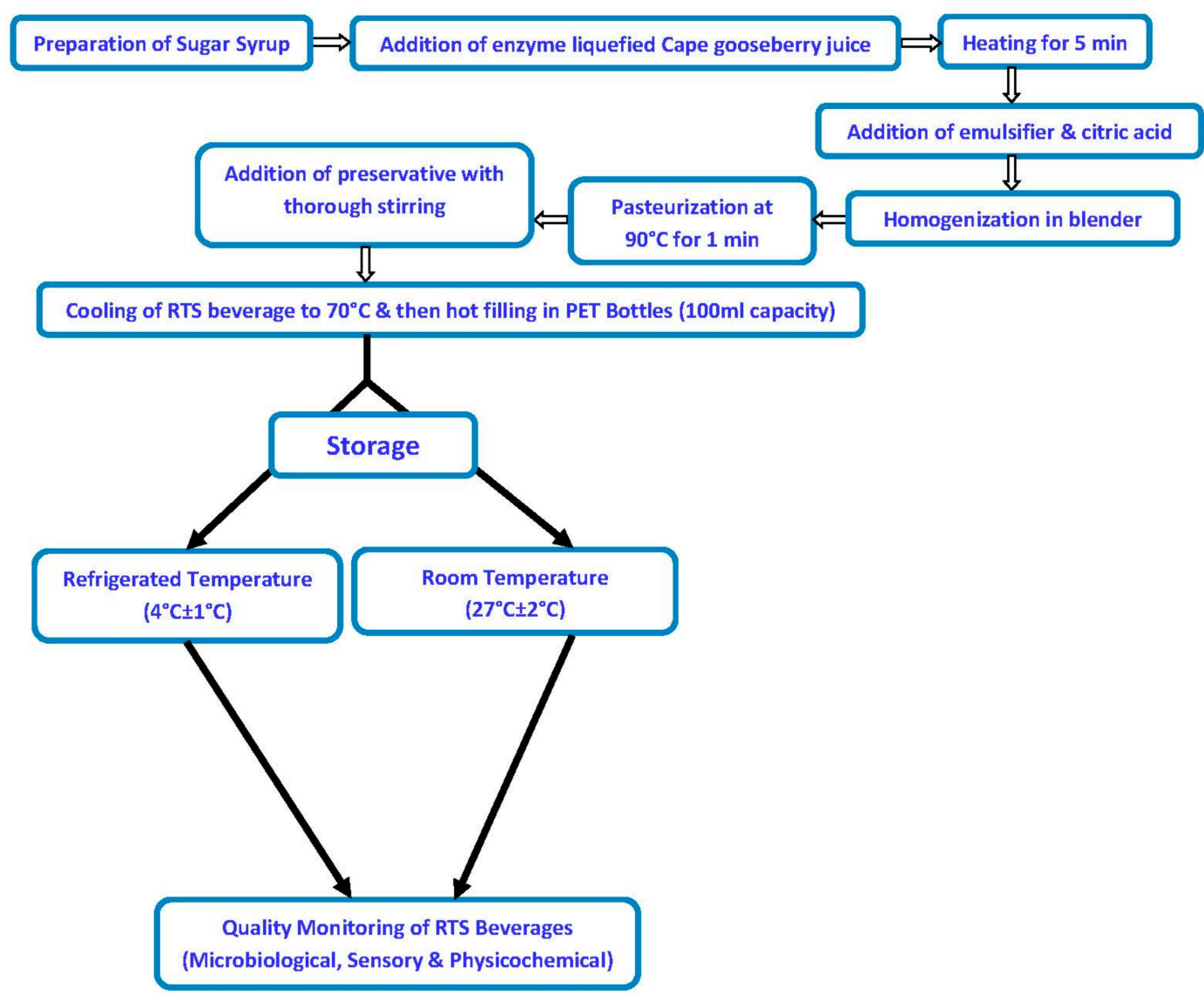

Figure 1. Flow Chart for the Preparation of Ready to Serve Beverage (RTS) from Enzyme Liquefied Juice of Cape gooseberry.

Viscosity

The viscosity is a crucial parameter for judging the consistency of the prepared RTS beverage, and it was measured using a Brookfield viscometer (Model: RV DV-II+ Pro) with spindle number-2 at a speed of $100 \mathrm{rpm}$ for $30 \mathrm{~s}$. Readings are noted in centipoise (cp).

\section{Total Soluble Solids}

The Total Soluble Solids (TSS) of the various RTS beverage samples were measured in triplicate using a calibrated hand refractometer (Model: Erma, Tokyo, Japan) and the reading observed was expressed in ${ }^{\circ}$ brix.

$\mathrm{pH}$

The $\mathrm{pH}$ of the sample was taken using a $\mathrm{pH}$ meter (Model: EUTECH Instruments-pH Tutor, Singapore). $20 \mathrm{~mL}$ of the RTS beverage sample was taken to dip the calibrated electrode of the $\mathrm{pH}$ meter and the observations were recorded in triplicate for each sample. 


\section{Titratable Acidity}

The acidity of the RTS beverage samples was carried out in triplicate using $0.01 \mathrm{~N} \mathrm{NaOH}$ solution and expressed as $\%$ anhydrous citric acid after using the formula as given below.

$$
\text { Titrable Acidity }(\%)=\frac{\text { Titre Value }(\mathrm{mL}) \times \mathrm{N} \mathrm{NaOH} \times \text { Volume }(\mathrm{mL}) \times \text { Eq. Weight }(\text { Citric Acid })}{\text { Sample Weight }(\mathrm{g}) \times \text { Aliquot Taken for Titration }(\mathrm{mL}) \times 1000} \times 100
$$

Ascorbic Acid

The ascorbic acid estimation was determined using the titrimetric method with 2,6dichlorophenolindophenol reagent as per the Association of Official Analytical Chemists [26] with a slight modification. Briefly, $10 \mathrm{~mL}$ of RTS beverage sample was mixed with $90 \mathrm{~mL}$ of $4 \%$ oxalic acid solution and filtered. From this, $5 \mathrm{~mL}$ of the filtrate was diluted to $15 \mathrm{~mL}$ with $4 \%$ oxalic acid solution and titrated against $0.02 \%$ of 2,6-dichlorophenolindophenol dye solution till the end point of light pink color persisted for $15 \mathrm{~s}$. The factor of dye solution (2,6-dichlorophenolindophenol) was obtained through titration using $0.05 \%$ standard ascorbic acid solution. The ascorbic acid calculated as per the following formula and expressed in mg per $100 \mathrm{~g}$.

Ascorbic acid content $(\mathrm{mg} / 100 \mathrm{~g})=\left(0.5 \mathrm{mg} / \mathrm{V}_{1}\right) \times\left(\mathrm{V}_{2} / 15 \mathrm{~mL}\right) \times(100 \mathrm{~mL} /$ wt. of Sample $) \times 100$

$\mathrm{V}_{1}$ and $\mathrm{V}_{2}$ are the volumes of dye solution used for standard ascorbic acid titration and also for the RTS beverage sample, respectively.

\section{Sugars}

The sugars such as \% reducing sugars (RS), \% non-reducing sugars (NRS) and \% total invert sugars (IS) (after inversion) in RTS beverage samples were determined as per the standard protocols of Lane and Eynon [27] to the brick red endpoint and calculated as per the following formula.

$$
\begin{gathered}
\text { Reducing sugars }(\%)=\text { Factor } \times \text { Dilution } \times \text { Volume } \times 100 / \text { Weight of sample } \times \text { Titer value } \\
\text { Total Invert Sugars }(\%)=\text { Factor } \times \text { Dilution } \times \text { Volume } \times 100 / \text { Weight of sample } \times \text { Titer value }
\end{gathered}
$$

\section{$\beta$-Carotene}

$10 \mathrm{~mL}$ of RTS beverage was taken and extracted with acetone till the color of the sample turned white and then it was filtered using Whatman filter paper no. $1.10-15 \mathrm{~mL}$ of petroleum ether along with $10 \mathrm{~mL}$ of water was added to a separating funnel containing the filtrate, thoroughly mixed, and allowed to stand few minutes for layer separation. The upper layer was then decanted and made up to volume as per the color intensity. The absorbance recorded at $452 \mathrm{~nm}$ in a UV-visible spectrophotometer (UV-1601, Shimadzu, Kyoto, Japan). The $\beta$-carotene, total carotene, and total carotenoids were calculated using the following formula and expressed as $\mathrm{mg} / 100 \mathrm{~mL}$ as per the procedure $[28,29]$.

$$
\begin{gathered}
\beta-\text { Carotene }(\mathrm{mg} / 100 \mathrm{~mL})=\frac{\text { O.D at } 452 \mathrm{~nm} \times 13.9 \times 10^{4} \times 100}{\text { The weight of the sample } \times 560 \times 1000} \\
\text { Total Carotene }(\mathrm{mg} / 100 \mathrm{~mL})=\frac{3.857 \times \text { O.D at } 452 \mathrm{~nm} \times \text { Final volume } \times \text { Dilution }}{\text { The weight of the sample }}
\end{gathered}
$$




\section{Total Phenolic Content}

The total phenolic content determination was done using the Folin-Ciocalteau assay as per the method [30]. The $10 \mathrm{~mL}$ sample was extracted with $80 \%$ ethanol, filtered, and concentrated using a rotary evaporator at $45^{\circ} \mathrm{C}$. After concentration, the sample was re-dissolved in $10 \mathrm{~mL}$ of methanol. The $100 \mu \mathrm{L}$ of extracted sample was mixed with $2.9 \mathrm{~mL}$ of distilled water in a tube and then $500 \mu \mathrm{L}$ of the Folin-Ciocalteau reagent was added. After the $3 \mathrm{~min}$ incubation period, $2 \mathrm{~mL}$ of $\mathrm{Na}_{2} \mathrm{CO}_{3}$ $(20 \%)$ solution was added to each tube and kept in the dark for $30 \mathrm{~min}$. The absorbance was taken at $765 \mathrm{~nm}$ against the reagent blank with the UV-visible spectrophotometer (UV-1601, Shimadzu, Kyoto, Japan). The total phenolic content was calculated using a standard calibration curve of gallic acid and expressed as $\mathrm{mg}$ of gallic acid equivalent (GAE)/100 mL of RTS beverage.

\subsection{Microbiological Analysis}

The RTS beverage may become contaminated during handling and processing. Therefore, contamination of the finished product makes it unfit for consumption. The microbiological analysis of the prepared and stored RTS beverages was done at regular intervals (before being subjected to sensory evaluation by the trained panelists), by standard protocols suggested by [31]. Some samples were further diluted serially and plated for a quantitative analysis of aerobic and anaerobic plate count, E. coli, Staphylococcus count, and yeast and mold count, using a culture media plate count agar $\left(37^{\circ} \mathrm{C} / 24 \mathrm{~h}\right)$, hi-chrome media $\left(37^{\circ} \mathrm{C} / 24 \mathrm{~h}\right)$, Baird Parker agar $\left(37^{\circ} \mathrm{C} / 48 \mathrm{~h}\right)$, and yeast mold agar $\left(25^{\circ} \mathrm{C} / 72 \mathrm{~h}\right)$, respectively. The standard pour plate method was adopted for the microbiological analysis of the RTS beverage samples. The samples were plated and kept for the incubation period of $24 \mathrm{~h}$ at $37^{\circ} \mathrm{C}$ for bacteria (total bacterial count, E. coli count and Staphylococcus count) and $72 \mathrm{~h}$ at $25 \pm 2{ }^{\circ} \mathrm{C}$ for yeast and mold count. The colonies developed after incubation at $37^{\circ} \mathrm{C}$ for $24-48 \mathrm{~h}$ were counted. The results are expressed as log $\mathrm{CFU} / \mathrm{mL}$. Each value of the data is presented as the mean of three replicates $(n=3)$.

\subsection{Sensory Analysis}

The sensory analysis was carried out for all RTS beverage samples stored at different temperatures LT $\left(4 \pm 1^{\circ} \mathrm{C}\right)$ and $\mathrm{RT}\left(27 \pm 2{ }^{\circ} \mathrm{C}\right)$ by a trained panel $(n=12)$ by using a 9-point hedonic scale for color, appearance, flavor, texture, taste, and overall acceptability. These samples were randomly served to the trained panelists in white cups coded with 3 digit random numbers. Each value of the sensory attributes data was presented as the mean of the twelve observations recorded by the trained panelists $(n=12)$.

\subsection{Statistical Analysis}

All of the experimental determinations were carried out in triplicate. The statistical analysis was performed with SPSS 16.0 software, using analysis of variance (ANOVA) and Duncan' Multiple Range Test (DMRT) with a 95\% confidence level $(p<0.05)$.

\section{Results and Discussion}

Results on the storage data were collected on various physicochemical changes, the microbial quality, and the sensory quality attributes of the RTS beverages stored both at refrigerated temperature (LT: $4{ }^{\circ} \mathrm{C} \pm 1{ }^{\circ} \mathrm{C}$ ) as well as room temperature (RT:27 ${ }^{\circ} \mathrm{C} \pm 2{ }^{\circ} \mathrm{C}$ ) conditions. They are presented in Table 1 and discussed. 
Table 1. Physicochemical changes in Cape gooseberry RTS beverages stored at Room Temperature (RT) $\left(27 \pm 2{ }^{\circ} \mathrm{C}\right)$ and Low Temperature (RT) $\left(27 \pm 2{ }^{\circ} \mathrm{C}\right)$ and (LT) $\left(4 \pm 1{ }^{\circ} \mathrm{C}\right)$ conditions.

\begin{tabular}{|c|c|c|c|c|c|c|c|c|c|c|c|c|c|}
\hline \multirow{3}{*}{\multicolumn{2}{|c|}{ Parameters }} & \multicolumn{12}{|c|}{ Storage Duration (in Days) } \\
\hline & & \multicolumn{2}{|c|}{0} & \multicolumn{2}{|c|}{15} & \multicolumn{2}{|c|}{30} & \multicolumn{2}{|c|}{45} & \multicolumn{2}{|c|}{60} & \multicolumn{2}{|c|}{90} \\
\hline & & RT & LT & RT & LT & RT & LT & RT & LT & RT & LT & RT & LT \\
\hline Color Values & $\begin{array}{l}\mathrm{L}^{*} \\
\mathrm{a}^{*} \\
\mathrm{~b}^{*}\end{array}$ & $\begin{array}{c}31.05 \pm 0.03^{\mathrm{a}} \\
2.99 \pm 0.03^{\mathrm{a}} \\
22.93 \pm 0.12^{\mathrm{a}}\end{array}$ & $\begin{array}{c}32.76 \pm 0.01^{\mathrm{a}} \\
2.74 \pm 0.01^{\mathrm{a}} \\
22.66 \pm 0.01^{\mathrm{d}}\end{array}$ & $\begin{array}{c}29.39 \pm 0.26^{\mathrm{b}} \\
2.03 \pm 0.03^{\mathrm{b}} \\
22.17 \pm 0.05^{\mathrm{b}}\end{array}$ & $\begin{array}{c}32.39 \pm 0.06^{\mathrm{a}} \\
2.17 \pm 0.07^{\mathrm{b}} \\
22.67 \pm 0.02^{\mathrm{d}}\end{array}$ & $\begin{array}{c}28.06 \pm 0.34^{\mathrm{c}} \\
1.66 \pm 0.06^{\mathrm{b}} \\
20.87 \pm 0.08^{\mathrm{c}}\end{array}$ & $\begin{array}{c}31.09 \pm 0.58^{\mathrm{b}} \\
1.74 \pm 0.01^{\mathrm{c}} \\
22.76 \pm 0.02^{\mathrm{cd}}\end{array}$ & $\begin{array}{c}28.22 \pm 0.26^{\mathrm{c}} \\
0.99 \pm 0.09^{\mathrm{c}} \\
19.17 \pm 0.15^{\mathrm{d}}\end{array}$ & $\begin{array}{c}28.81 \pm 0.09^{\mathrm{c}} \\
1.43 \pm 0.12^{\mathrm{d}} \\
22.86 \pm 0.09^{\mathrm{c}}\end{array}$ & $\begin{array}{c}28.22 \pm 0.26^{\mathrm{c}} \\
-0.08 \pm 0.35^{\mathrm{d}} \\
15.17 \pm 0.15^{\mathrm{e}}\end{array}$ & $\begin{array}{c}28.38 \pm 0.81^{\mathrm{c}} \\
0.76 \pm 0.09^{\mathrm{e}} \\
23.22 \pm 0.08^{\mathrm{b}}\end{array}$ & $\begin{array}{c}26.86 \pm 0.03^{\mathrm{d}} \\
-0.69 \pm 0.51^{\mathrm{e}} \\
9.17 \pm 0.15^{\mathrm{f}}\end{array}$ & $\begin{array}{c}26.33 \pm 0.03^{\mathrm{d}} \\
-0.57 \pm 0.01^{\mathrm{f}} \\
23.80 \pm 0.09^{\mathrm{a}}\end{array}$ \\
\hline \multicolumn{2}{|c|}{ Viscosity (cp) } & $28.73 \pm 0.25^{\mathrm{a}}$ & $28.74 \pm 0.01^{\mathrm{a}}$ & $28.74 \pm 0.01^{\mathrm{a}}$ & $28.76 \pm 0.02^{a}$ & $28.55 \pm 0.04^{\mathrm{a}}$ & $28.82 \pm 0.02^{\mathrm{a}}$ & $28.36 \pm 0.01^{\mathrm{b}}$ & $28.88 \pm 0.07^{a}$ & $28.07 \pm 0.05^{c}$ & $29.36 \pm 0.11^{b}$ & $27.79 \pm 0.01^{d}$ & $30.29 \pm 0.04^{c}$ \\
\hline \multicolumn{2}{|c|}{ TSS $\left({ }^{\circ}\right.$ Brix $)$} & $14.17 \pm 0.21^{\mathrm{d}}$ & $14.13 \pm 0.05^{\mathrm{e}}$ & $14.13 \pm 0.05^{\mathrm{e}}$ & $14.17 \pm 0.06$ de & $14.37 \pm 0.06^{\mathrm{cd}}$ & $14.27 \pm 0.06^{\mathrm{d}}$ & $14.50 \pm 0.17 \mathrm{bc}$ & $14.47 \pm 0.06^{c}$ & $15.20 \pm 0.10^{\mathrm{a}}$ & $14.75 \pm 0.01^{\mathrm{b}}$ & $14.63 \pm 0.06^{\mathrm{b}}$ & $15.03 \pm 0.06^{\mathrm{a}}$ \\
\hline \multicolumn{2}{|c|}{$\mathrm{pH}$} & $3.41 \pm 0.01^{\mathrm{a}}$ & $3.35 \pm 0.02^{\mathrm{a}}$ & $3.35 \pm 0.02^{\mathrm{a}}$ & $3.32 \pm 0.01^{\mathrm{b}}$ & $3.30 \pm 0.01^{\mathrm{c}}$ & $3.26 \pm 0.01^{\mathrm{c}}$ & $3.25 \pm 0.02^{\mathrm{d}}$ & $3.21 \pm 0.01 \mathrm{~d}$ & $3.19 \pm 0.01^{\mathrm{e}}$ & $3.11 \pm 0.00^{\mathrm{e}}$ & $2.85 \pm 0.01^{\mathrm{f}}$ & $2.99 \pm 0.00^{\mathrm{f}}$ \\
\hline \multicolumn{2}{|c|}{ Titratable Acidity (\%) } & $0.58 \pm 0.00^{\mathrm{a}}$ & $0.51 \pm 0.00^{\mathrm{a}}$ & $0.51 \pm 0.00^{\mathrm{a}}$ & $0.50 \pm 0.11^{\mathrm{b}}$ & $0.45 \pm 0.01^{\mathrm{c}}$ & $0.46 \pm 0.01^{\mathrm{c}}$ & $0.39 \pm 0.00^{d}$ & $0.39 \pm 0.01^{\mathrm{d}}$ & $0.32 \pm 0.01^{\mathrm{e}}$ & $0.35 \pm 0.01^{\mathrm{e}}$ & $0.34 \pm 0.01^{f}$ & $0.30 \pm 0.01^{\mathrm{f}}$ \\
\hline \multicolumn{2}{|c|}{ Ascorbic acid (mg/100 mL) } & $26.64 \pm 0.06^{\mathrm{a}}$ & $26.64 \pm 0.05^{\mathrm{a}}$ & $26.64 \pm 0.05^{a}$ & $26.05 \pm 0.40^{\mathrm{b}}$ & $19.35 \pm 0.02^{c}$ & $24.54 \pm 0.23^{c}$ & $16.35 \pm 0.02^{\mathrm{d}}$ & $22.17 \pm 0.52^{\mathrm{d}}$ & $12.47 \pm 0.00^{\mathrm{e}}$ & $18.64 \pm 0.06^{\mathrm{e}}$ & $8.23 \pm 0.03^{\mathrm{e}}$ & $15.44 \pm 0.09^{\mathrm{f}}$ \\
\hline \multicolumn{2}{|c|}{ Reducing Sugar $(\%)$} & $3.23 \pm 0.00^{f}$ & $3.23 \pm 0.00^{f}$ & $3.23 \pm 0.00^{\mathrm{f}}$ & $3.33 \pm 0.11^{\mathrm{e}}$ & $4.02 \pm 0.01 \mathrm{~d}$ & $3.58 \pm 0.02^{d}$ & $4.64 \pm 0.01^{\mathrm{c}}$ & $3.95 \pm 0.02^{\mathrm{c}}$ & $5.57 \pm 0.01 \mathrm{~b}$ & $4.55 \pm 0.03^{b}$ & $6.59 \pm 0.01^{\mathrm{a}}$ & $5.93 \pm 0.11^{\mathrm{a}}$ \\
\hline \multicolumn{2}{|c|}{ Non-reducing sugar $(\%)$} & $9.88 \pm 0.05^{\mathrm{a}}$ & $9.88 \pm 0.05^{\mathrm{a}}$ & $9.88 \pm 0.05^{a}$ & $9.79 \pm 0.04^{b}$ & $9.31 \pm 0.02^{c}$ & $9.64 \pm 0.01^{c}$ & $8.79 \pm 0.01 \mathrm{~d}$ & $9.43 \pm 0.01^{\mathrm{d}}$ & $8.26 \pm 0.01 \mathrm{e}$ & $9.11 \pm 0.02 \mathrm{e}$ & $7.13 \pm 0.02^{f}$ & $8.12 \pm 0.00^{\mathrm{f}}$ \\
\hline \multicolumn{2}{|c|}{ Total sugars (\%) } & $13.10 \pm 0.05^{\mathrm{f}}$ & $13.10 \pm 0.05^{\mathrm{e}}$ & $13.10 \pm 0.05^{\mathrm{e}}$ & $13.12 \pm 0.12^{\mathrm{e}}$ & $13.29 \pm 0.02^{\mathrm{d}}$ & $13.22 \pm 0.02^{\mathrm{d}}$ & $13.43 \pm 0.00^{c}$ & $13.37 \pm 0.35^{c}$ & $13.83 \pm 0.01^{\mathrm{a}}$ & $13.66 \pm 0.03^{b}$ & $13.72 \pm 0.01^{\mathrm{b}}$ & $14.05 \pm 0.02^{\mathrm{a}}$ \\
\hline \multicolumn{2}{|c|}{$\beta$-carotene $(\mathrm{mg} / 100 \mathrm{~mL})$} & $0.98 \pm 0.01^{\mathrm{a}}$ & $0.98 \pm 0.01^{\mathrm{a}}$ & $0.98 \pm 0.01^{\mathrm{a}}$ & $0.98 \pm 0.00^{\mathrm{a}}$ & $0.86 \pm 0.00^{c}$ & $0.96 \pm 0.01^{\mathrm{a}}$ & $0.78 \pm 0.00^{\mathrm{d}}$ & $0.90 \pm 0.01^{\mathrm{b}}$ & $0.66 \pm 0.02^{\mathrm{e}}$ & $0.88 \pm 0.01^{\mathrm{c}}$ & $0.37 \pm 0.01^{\mathrm{f}}$ & $0.78 \pm 0.02^{\mathrm{d}}$ \\
\hline \multicolumn{2}{|c|}{ Total carotene $(\mathrm{mg} / 100 \mathrm{~mL})$} & $1.61 \pm 0.02^{\mathrm{a}}$ & $1.61 \pm 0.02^{\mathrm{a}}$ & $1.61 \pm 0.02^{\mathrm{a}}$ & $1.60 \pm 0.02^{\mathrm{a}}$ & $1.33 \pm 0.00^{c}$ & $1.58 \pm 0.01^{\mathrm{b}}$ & $1.11 \pm 0.00^{\mathrm{d}}$ & $1.47 \pm 0.01^{\mathrm{c}}$ & $0.68 \pm 0.02^{\mathrm{e}}$ & $1.29 \pm 0.01^{\mathrm{d}}$ & $0.50 \pm 0.00^{\mathrm{f}}$ & $1.07 \pm 0.01^{\mathrm{e}}$ \\
\hline \multicolumn{2}{|c|}{ Total phenolic (mg GAE/100 mL) } & $21.83 \pm 0.12^{\mathrm{a}}$ & $21.83 \pm 0.12^{a}$ & $21.83 \pm 0.12^{\mathrm{a}}$ & $21.78 \pm 0.03$ a & $19.13 \pm 0.03^{c}$ & $19.78 \pm 0.03^{\mathrm{b}}$ & $17.67 \pm 0.03^{\mathrm{d}}$ & $18.17 \pm 0.03^{c}$ & $15.03 \pm 0.05^{\mathrm{e}}$ & $17.17 \pm 0.03^{\mathrm{d}}$ & $8.00 \pm 0.03^{f}$ & $15.56 \pm 0.00^{\mathrm{e}}$ \\
\hline
\end{tabular}

Note: $(n=3$; average $\pm \mathrm{SD})$, values in rows with different superscripts (a-f) have significant differences at $p<0.05$ by DMRT Test. $\mathrm{L}^{*}$ indicates luminosity, $\mathrm{a}^{*}$ corresponds to greenness

$(-)$ /redness $(+)$, and $b^{*}$ corresponds to blueness $(-)$ /yellowness $(+)$. 


\subsection{Physico-Chemical Properties}

\subsubsection{Changes in Color}

The color of beverage samples during storage showed significant $(p \leq 0.05)$ changes in $\mathrm{L}^{*}$ values after 90 days of storage at $\mathrm{LT}\left(4^{\circ} \mathrm{C} \pm 1^{\circ} \mathrm{C}\right)$ and RT $\left(27^{\circ} \mathrm{C} \pm 2{ }^{\circ} \mathrm{C}\right)$ conditions (Table 1$)$. RT stored RTS beverage samples were found to be slightly lighter in appearance than LT stored samples concerning lightness $\left(\mathrm{L}^{*}\right)$. The * (redness) values also showed the similar trend. There was slight but significant increase in $b^{*}$ (yellowness) values in LT stored RTS beverage samples and became more intense and yellowish on prolonged storage. In contrast, RT stored samples showed the decrease in $b^{*}$ values, and it is the indicative towards the reduction in yellowness. The rapid color change in RT stored samples could be due to the long-term effect of high temperature during storage and also might be due to oxidative and enzymatic degradation of the major pigments [32]. The temperature and storage period had a significant effect on total color change, which indicates the magnitude of the color difference. The variations in the color values in RT stored samples were possibly affected by the oxidative and non-oxidative propensity of polyphenolic contents towards somewhat colored condensation products [33]. It also could be due to the condensation and destruction of pigments by the Maillard reaction or melanoidins formation that may cause the deterioration in color [34].

\subsubsection{Changes in Viscosity}

The RTS beverage, in general, is well known as a non-Newtonian fluid. A significant increase was observed in the viscosity of samples (Table 1) stored at LT $\left(4^{\circ} \mathrm{C} \pm 1^{\circ} \mathrm{C}\right)$, while for the RT $\left(27^{\circ} \mathrm{C} \pm 2{ }^{\circ} \mathrm{C}\right)$ stored samples, there was a slight increment in viscosity values during the first 45 days and then they began to decrease after 60 days, which may be due to the enzymatic and bacterial degradation of polysaccharides like pectin and starch in beverage samples [35]. Hence, there will be an increase of strain and shearing rate, a decrease of flow index, and a decreased inconsistency of the product with a rise in temperature. The flow index of the RTS beverage samples decrease, which helps to develop a pseudo plasticity and an increase in viscosity [36]. The increase in viscosity of the RTS beverage samples could be explained by the interactions of the pectin molecule, citric acid, sugar, and liquid phase of the RTS beverage of Cape gooseberry. The hydrogen bonding with hydroxyl groups of solutes can also be responsible for increasing the viscosity of juice, and it can play a vital role in the magnitude of viscosity [36]. Pectin as an emulsifier was added to prevent sedimentation in the Cape gooseberry RTS beverage. The pertinacious material can possess higher water holding capacity and develop a cohesive network structure [37,38] and pectin is known to be highly hygroscopic in nature so it will imbibe with water to form a gel-like network [39]. Along with other ingredients like citric acid and sugar, pectin may also play a vital role to modify the rheology of the Cape gooseberry RTS beverage.

Pectin is a thickening agent, and it can form viscous solutions with water to increase the viscosity in beverages. Pectin is considered a thickening and stabilizing agent because it can form colloidal solutions and can contribute to higher viscosity. The observed reduction in the $\mathrm{pH}$ of RTS beverage would render the pectin molecules reduced in hydrophilic portions, contributing to a great tendency to form a gel kind of network in the liquid phase, which could be vital in enhancing the viscosity of juice-based beverages [40].

\subsubsection{Changes in Total Soluble Solids}

The TSS significantly increased in LT and RT stored samples (Table 1). Increase in the pools of TSS of the product could be due to the hydrolysis of the polysaccharides (such as starch and pectin) into simple sugars such as monosaccharides (such as glucose and fructose) and oligosaccharides (sucrose) and other constituents [32,41-45]. Similar changes in TSS during storage were also reported in functional ready to serve (RTS) drinks made from a blend of Aloe vera, sweet lime, amla, and ginger [46]. 


\subsubsection{Changes in $\mathrm{pH}$}

The $\mathrm{pH}$ of the RTS beverage is directly dependent on the inherent total organic acids of fruit and indirectly proportionate to the added organic acid content during the product's preparation. As the $\mathrm{pH}$ of the RTS beverage is an attribute that is due to the inherent total organic acids present in the gooseberry and also due to the added citric acid content during RTS beverage preparation that affects the flavor enhancement and product preservation during storage. The decrease in $\mathrm{pH}$ value was found to be $(p \leq 0.05)$ for both LT as well as RT stored RTS beverage samples (Table 1$)$. The RTS beverage samples kept at RT had lower $\mathrm{pH}$ values than the LT stored ones. This might be due to the storage conditions, which may have led to chemical and enzymatic changes in RTS beverage properties [47].

\subsubsection{Changes in Acidity}

The acidity of any food product (as \% Anhydrous Citric Acid) is the first preference of a consumer for acceptance, and it is considered to be a dependent attribute of the RTS beverage. The acidity of RTS beverages decreased with increases in storage duration (Table 1). The acidity in LT and RT stored RTS beverage samples have decreased gradually from 0.58 to $0.38 \%$ during their storage and also up to the prolonged storage period. These changes in the decrease of acidity might be due to the acidic hydrolysis of the polysaccharides, where the acid is utilized for converting non RS into RS [48]. In the case of the samples at RT, the acidity decreased till 60 days, then increases in acidity were observed. A similar observation was reported by [49] while checking the effect of heat processing on the discoloration of custard apple fruit pulp and changes in quality characteristics during storage.

\subsubsection{Changes in Ascorbic Acid}

Ascorbic acid (vitamin-C) is considered to be a heat-labile vitamin and most sensitive towards light and higher temperature. The loss of ascorbic acid content of RTS beverages observed in both LT as well as RT stored samples (Table 1). LT stored RTS beverage samples showed higher ascorbic content than the RT stored RTS beverage samples. The degradation in ascorbic acid content in RT stored RTS beverage samples could be because of oxidation, due to the presence of oxygen trapped in packaged PET bottles; there it would be possible for the formation of dehydroascorbic acid in the presence of enzyme ascorbic acid oxidase, or even other factors such as heat processing and storage temperature might also be responsible [50].

\subsubsection{Changes in Sugar Content}

The RTS beverage samples were analyzed for changes in reducing sugars (RS), invert sugars (IS) and total sugars (TS) during storage. The RS percentage was $(p \leq 0.05)$ increased 3.23 to $6.59 \%$ in RT stored samples during a prolonged storage duration (Table 1). While the RS percentage in LT stored samples was $(p \leq 0.05)$ increased from 3.23 to $5.93 \%$. Whereas, the NRS percentage $(p \leq 0.05)$ decreased irrespective of the storage temperatures, losses were observed more in RT stored samples (9.88 to 7.13\%) in comparison with LT stored samples ( 9.88 to $8.12 \%$ ), which could be due to temperature influence. The increase in RS could be due to the conversion of NRS through the process of glucogenesis to RS [51] and also organic acid hydrolysis in the stored sample [52]. The TRS content was increased $(p \leq 0.05)$ during the storage as shown in (Table 1), which could be due to the hydrolysis of the disaccharides and polysaccharides into soluble sugars [53,54]. There is even a possibility of starch hydrolysis due to the presence of citric acid, therefore RS content may increase during prolonged storage of both RT and LT stored samples, irrespective of the storage conditions [51-54]. There was a slight decrease in TS content from day 60 to day 90 (13.83 to $13.72 \%$ ) observed in RT stored samples that may be due to the microbial growth, as observed through experimentation of microbial counts by the pour plate method (Table1). 


\subsubsection{Changes in $\beta$-Carotene and Total Carotenes}

The carotene content of the Cape gooseberry RTS beverage samples showed a $(p \leq 0.05)$ decrease in total carotene content (Table 1). The samples stored at LT recorded a decrease in total carotene (1.61 to $1.07 \mathrm{mg} / 100 \mathrm{~mL})$ and $\beta$-carotene content $(0.98$ to $0.78 \mathrm{mg} / 100 \mathrm{~mL})$. There were higher losses of carotene content found in RT stored samples. The total carotene content decreased from 1.61 to $0.50 \mathrm{mg} / 100 \mathrm{~mL}$ and $\beta$-carotene $(0.98$ to $0.37 \mathrm{mg} / 100 \mathrm{~mL}$ ) in RT stored samples. This significant decrease in total carotenoids content could be due to oxidative reactions, isomeric conversion, or changes in pigments due to enzymatic destruction [55]. However, there was a greater decline in the carotenoids content observed after 60 days storage in the LT stored samples, which further can be due to the microbial growth as observed through the experimentation of microbial counts.

\subsubsection{Total Phenolic Content}

The results revealed that there was a gradual decrease in total phenolic content in Cape gooseberry RTS beverage samples stored at LT and RT (Table 1). The LT stored samples showed the higher retention of total phenolic compounds ( 21.83 to $15.56 \mathrm{mg}$ GAE/100 mL) in comparison to RT stored samples ( 21.83 to $8.03 \mathrm{mg} \mathrm{GAE} / 100 \mathrm{~mL}$ ) during a 90 day storage period. These changes indicate that LT is a better preserving storage conditions for RTS beverage to store for longer duration.

This gradual reduction in total phenolic content during storage of RTS beverages at LT \& RT conditions might be due to their polymeric oxidation towards the formation of brown pigments. Similar trends were observed by other researchers in various beverages like Jamun squash and guava-jamun blended squash [56,57]. Even though phenolic compounds play some vital role in the quality of processed food products like flavor and taste, they have specific and important health-promoting properties [56]. The astringency taste of the phenolic compounds in strawberry jam and also the fluctuations in phenolic content, ascorbic acid and total carotenoids, and antioxidant activity of fruit beverages during storage was earlier investigated $[58,59]$.

\subsection{Microbiological Evaluation}

Despite the high water contents and nutrients present, the low $\mathrm{pH}$ of the RTS Cape gooseberry beverage prevented the growth of microorganisms. Initially, there was no microbial count in the prepared RTS beverage samples. There was no bacterial, yeast, or mold growth observed in the LT stored samples, throughout their shelf life study for 90 days. In the case of the RT stored samples, there was no growth seen over the 45 -day storage period. After that, very little growth of bacteria was observed concerning the total plate count $(0.698 \log \mathrm{CFU} / \mathrm{mL})$ at the completion of 60 days. The quality of RT stored samples started degrading after 60 days, and there was higher bacterial growth observed $(1.505 \log$ CFU $/ \mathrm{mL})$ at the end of 90 days, but it was within the permissible limit and also a fading of the RTS beverage color was also observed. These reported microbiological values are within the permissible limits of [7]. Therefore, the data results of all of the above mentioned microbiological quality attributes for both LT and RT stored samples are not presented. As per [7], the microbiological requirements of fruit juices, carbonated beverages, ready to serve beverages including fruit beverages are not more than $50 \mathrm{CFU} / \mathrm{mL}$ for TPC, not more than $2 \mathrm{cfu} / \mathrm{mL}$ for YMC, and absent in $100 \mathrm{~mL}$ for the E. coli count. Results indicated that the microbial growth observed in the RT stored samples only considered bacterial growth (belong to genera Bacillus), which is observed to be the common microbial contaminant and commonly reported from the air [60]. The low counts observed in the LT \& RT stored samples is probably a result of spore-forming bacteria that could not achieve the favorable conditions to multiply due to the acidic medium of the RTS beverage. The coliform count was undetectable in all the RTS beverage samples stored at LT and RT conditions. Therefore, it is concluded that relatively high pasteurization temperature $\left(90^{\circ} \mathrm{C}\right.$ for $\left.1 \mathrm{~min}\right)$ and low $\mathrm{pH}(\sim 4.00)$ of the RTS beverage has synergistically impeded the growth of the coliform bacteria and it has resulted in a safe to consume RTS beverage during storage. 


\subsection{Sensory Evaluation}

Figure 2a,b illustrates the sensory profiles based on the mean scores for all the quality attributes (color, appearance, flavor, texture, taste and overall acceptability) of the samples stored at two different temperatures $\mathrm{LT}\left(4 \pm 1{ }^{\circ} \mathrm{C}\right)$ and $\mathrm{RT}\left(27 \pm 2{ }^{\circ} \mathrm{C}\right)$. Initially, all the samples got a score of 9.00 by all the panelists for all of the above quality attributes. During the shelf life storage study, there were slight changes in the sensory score for LT stored samples with an overall quality attribute score of 8.3 (Figure 2a). In the RT stored samples, there were few changes in all the above sensory quality attributes observed for the first 60 days, thereafter, there was a degradation in the quality attributes of RT stored samples, which rapidly changed particularly with respect to changes in color, flavor, taste. At the end of storage the overall acceptability score was 6.5 (Figure 2b).

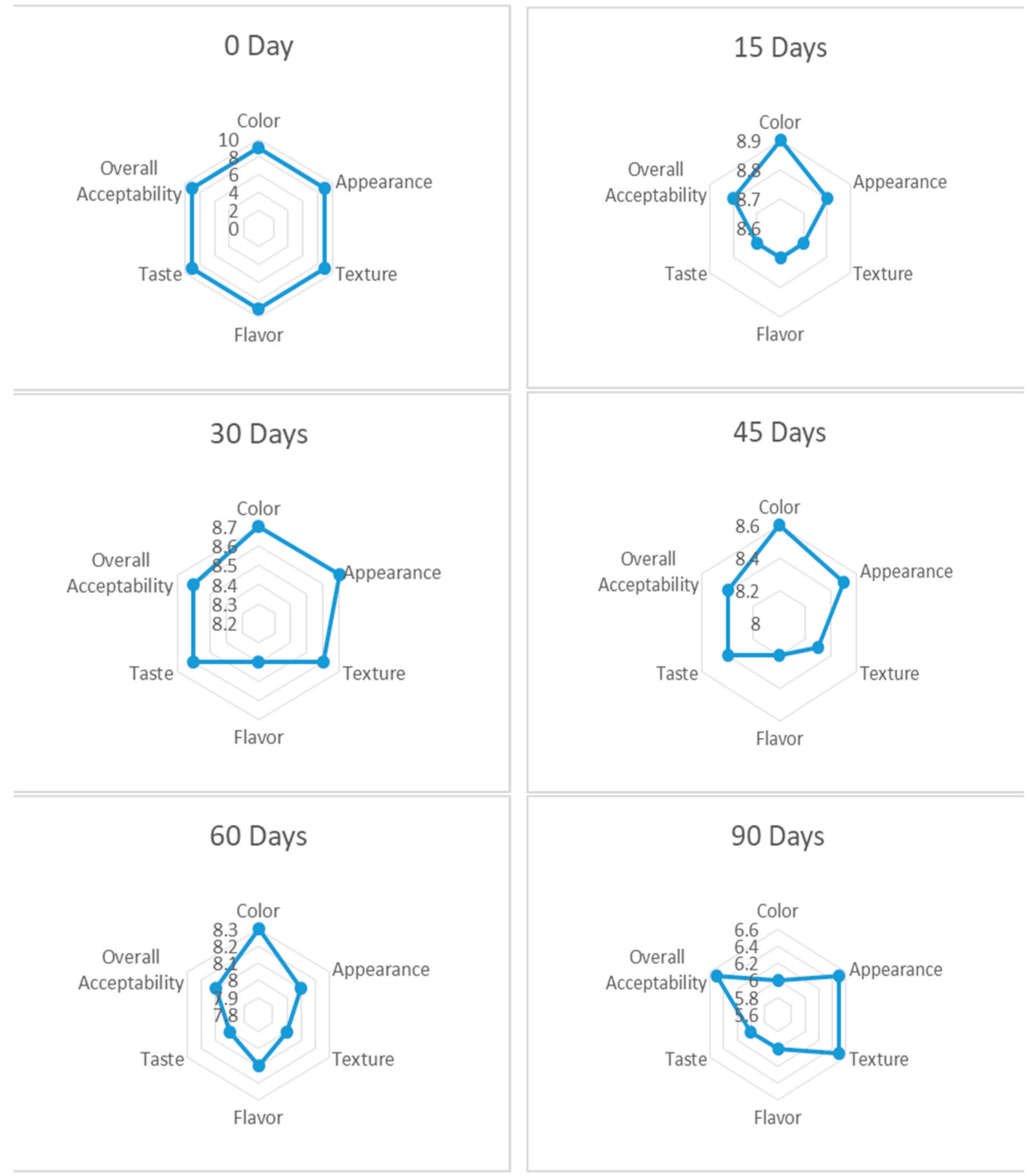

(a)

Figure 2. Cont. 


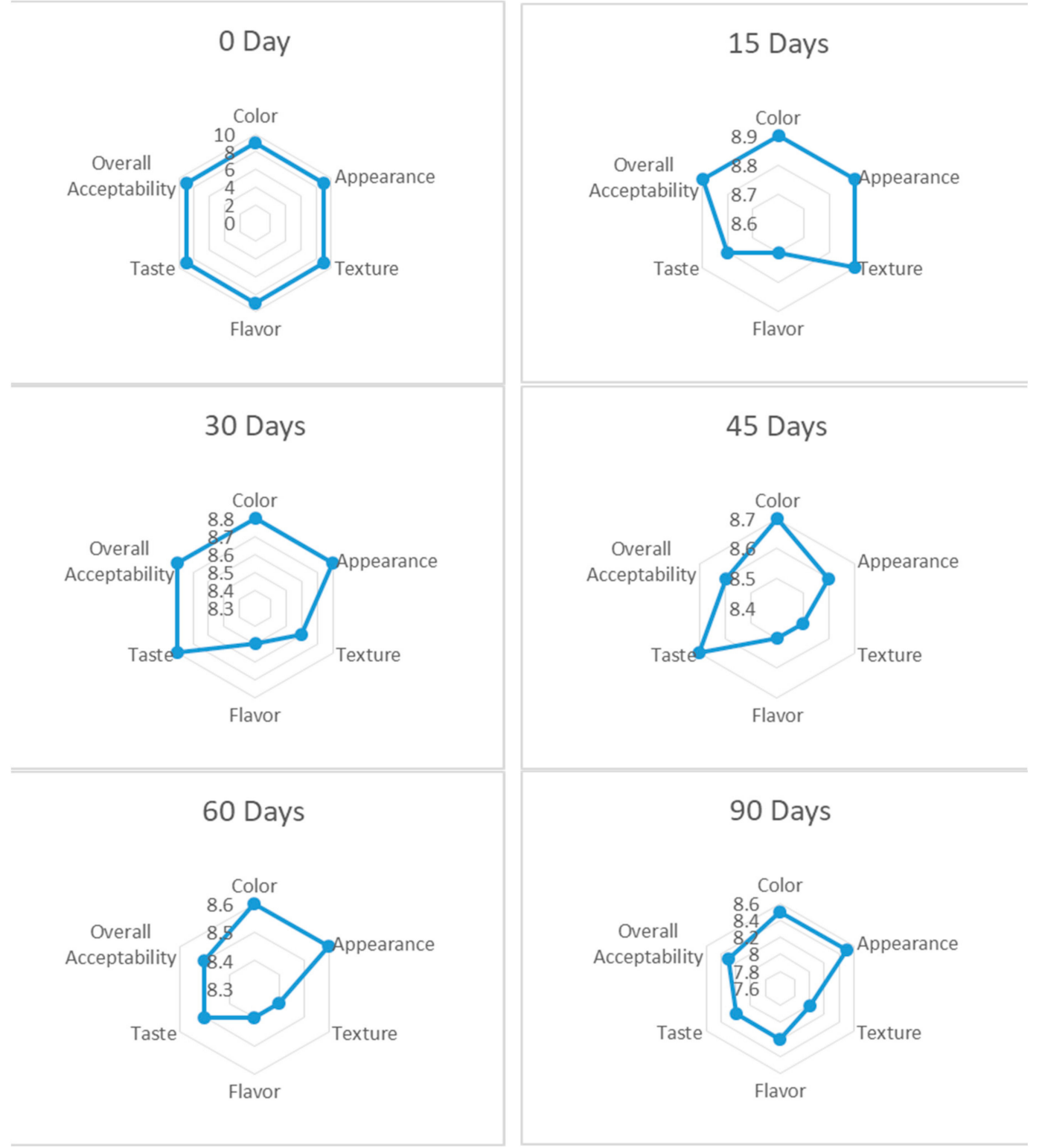

(b)

Figure 2. (a) Sensory profile of ready to serve beverage of Cape gooseberry during storage at Room Temperature (RT) $\left(27 \pm 2{ }^{\circ} \mathrm{C}\right)$; (b) Sensory profile of ready to serve beverage of Cape gooseberry during storage at Low Temperature (LT) $\left(4 \pm 1^{\circ} \mathrm{C}\right)$.

\section{Conclusions}

In this study, a RTS beverage was formulated from enzyme liquefied Cape gooseberry juice. Shelf-life studies on the RTS beverage were prepared at varying storage temperatures, such as LT $\left(4{ }^{\circ} \mathrm{C} \pm 1{ }^{\circ} \mathrm{C}\right)$ and $\mathrm{RT}\left(27^{\circ} \mathrm{C} \pm 2{ }^{\circ} \mathrm{C}\right)$ for a storage period of 90 days. The RTS beverage samples stored at LT $\left(4^{\circ} \mathrm{C} \pm 1{ }^{\circ} \mathrm{C}\right)$ showed less physicochemical degradations and had good sensorial acceptability regarding sensory attributes (color and overall quality), were microbiologically safe, and also retained their nutritional values regarding ascorbic acid and $\beta$-carotene. RT $\left(27^{\circ} \mathrm{C} \pm 2{ }^{\circ} \mathrm{C}\right)$ stored RTS beverage samples were also well accepted for 60 days regarding sensory quality. The RTS beverage of Cape gooseberry juice possessed ascorbic acid, $\beta$-carotene, total phenolic contents, and was consistently stored in a stable environment with above average quality attributes up to 90 days when stored at LT $\left(4^{\circ} \mathrm{C} \pm 1{ }^{\circ} \mathrm{C}\right)$. However, the microbiological quality (in terms of bacterial growth) of RT stored 
samples was within the permissible limit at the end of 90 days. It could be used as an alternative to synthetic soft drinks as a result of its nutritional quality and functional properties. Therefore, it can be recommended as a health drink for better sustainability in both the national and global market for consumption and export purposes.

Author Contributions: R.H. performed the experiments; A.K. sourced, selected raw material and collected data; O.P. analyzed the data; A.S. did sensory and microbial analysis of product; A.S.C. produced development and wrote the paper; V.B.K. overall taken planning, execution and coordination of experiments and wrote the paper.

Acknowledgments: The authors acknowledge the CSIR, New Delhi, India for funding the Dissertation and Project work and also express their sincere thanks to Director, CSIR-CFTRI, Mysore for his keen interest, constant encouragement, and kind support during this study. Authors also extend their sincere thanks to the Head and the Staff of CIFS, CSIR-CFTRI for their technical assistance in instrumental analysis of the RTS beverage samples.

Conflicts of Interest: The authors declare no conflict of interest.

\section{References}

1. National Horticulture Board of India. Solvent and enzyme-aided aqueous extraction of golden berry (Physalis peruviana L.) pomace oil: Impact of processing on composition and quality of oil and meal. In Horticultural Statistics at a Glance 2015; Oxford University Press: New Delhi, India, 2016; pp. 1-14.

2. Ramadan, M.F.; Sitohy, M.Z.; Mörsel, J.T. Solvent and enzyme-aided aqueous extraction of golden berry (Physalis peruviana L.) pomace oil: Impact of processing on composition and quality of oil and meal. Eur. Food Res. Technol. 2008, 226, 1445-1458. [CrossRef]

3. Puente, L.A.; Muñoz, C.A.P.; Castro, E.S.; Cortes, M. Physalis peruviana Linnaeus, the multiple properties of a highly functional fruit: A review. Food Res. Int. 2011, 44, 1733-1740. [CrossRef]

4. Ramadan, M.F.; Mörsel, J.T. Impact of enzymatic treatment on chemical composition, physicochemical properties and radical scavenging activity of golden berry (Physalis peruviana L.) juice. J. Sci. Food Agric. 2007, 87, 452-460. [CrossRef]

5. Ramadan, M.F.; Mörsel, J.T. Oil extractability from enzymatically-treated golden berry (Physalis peruviana L.) pomace: Range of operational variables. Int. J. Food Sci. Technol. 2009, 44, 435-444. [CrossRef]

6. Ramadan, M.F.; Mörsel, J.T. Physalis peruviana: A rich source of bioactive phytochemicals for functional foods and pharmaceuticals. Food Rev. Int. 2011, 27, 259-273.

7. Directions Under Section 16(5) of the Food Safety and Standards Act, 2006 Regarding Operationalization of Food Safety and Standards (Food Products Standards and Food Additives) Amendment Regulations, 2017 Relating to Standards for Non-Carbonatedwaterbasedbeverages (NonAlcoholic). (Ref.No:Stds/ SP(WaterandBeverages)Notif(1)/ FSSAI-2016(PartII), FSSAI, FDA Bhawan, Kotla Road, New Delhi, 2017. Available online: https://www.google.co.in/search?q=7.+FSSAI,+Directions+Direction_Non_Carbonated_Water_ Standard_07_07_2017(3).pdf (accessed on 5 June 2018).

8. Zhao, Y. Berry Fruit: Value-Added Products for Health Promotion; Zhao, Y., Ed.; CRC Press: Boca Raton, NY, USA, 2007; Volume 168, pp. 101-206.

9. Motooka, P.; Castro, L.; Nelson, D.; Nagai, G.; Ching, L. Weeds of Hawaii's Pastures and Natural Areas: An Identification and Management Guide; College of Tropical Agriculture and Human Resources, University of Hawaii, Manoa, HI, USA, 2003. Available online: https://www.ctahr.hawaii.edu/invweed/ weedsHi.html (accessed on 2 May 2018).

10. Novoa, H.R.; Bojaca, M.; Galvis, J.A.; Fischer, G. Fruit maturity and calyx drying influence post-harvest behavior of Cape gooseberry (Physalis peruviana L.) stored at $12{ }^{\circ} \mathrm{C}$. Agron. Colomb. 2006, 24, 77-86.

11. Ramadan, M.F.; Mörsel, J.T. Golden berry: A novel fruit source of fat-soluble bioactive. Inform 2004, 15, $130-131$.

12. Mayorga, H.; Knapp, H.; Winter halter, P.; Duque, C. Glycosidically bound flavor compounds of Cape gooseberry (Physalis peruviana L.). J. Agric. Food Chem. 2001, 49, 1904-1908. [CrossRef] [PubMed]

13. Tapia, M.; Fries, A. Guía de Campo de los Cultivos and Inos; FAO y ANPE: Lima, Peru, 2007.

14. Erkaya, T.; Dağdemir, E.; Şengül, M. Influence of Cape gooseberry (Physalis peruviana L.) addition on the chemical and sensory characteristics and mineral concentrations of ice cream. Food Res. Int. 2012, 45, 331-335. [CrossRef] 
15. Deb, B. Solanaceae in India: The Biology and Taxonomy of Solanaceae; Hawkes, J., Lester, R., Skelding, A., Eds.; Academic Press: London, UK, 1979; pp. 3-48.

16. Rodrigues, E.; Rockenbach, I.I.; Cataneo, C.; Gonzaga, L.V.; Chaves, E.S.; Fett, R. Minerals and essential fatty acids of the exotic fruit Physalis peruviana L. Food Sci. Technol. 2009, 29, 642-645. [CrossRef]

17. Valdenegro, M.; Henriquez, C.; Lutz, M.; Almonacid, S.; Simpson, R. Drum dried, lyophilized dried and traditional drying of golden berry (Physalis peruviana L.): Effects in nutritional and healthy quality. In Proceedings of International Conference on Food Innovation, Universidad Politècnica de valència, Valencia, Spain, 25-29 October 2010.

18. Ramadan, M.F. Bioactive phytochemicals, nutritional value, and functional properties of cape gooseberry (Physalis peruviana): An overview. Food Res. Int. 2011, 44, 1830-1836. [CrossRef]

19. Yen, C.Y.; Chiu, C.C.; Chang, F.R. 4-Hydroxywithanolide E from Physalis peruviana (golden berry) inhibits the growth of human lung cancer cells through DNA damage, apoptosis, and G2/M arrest. BMC Cancer 2010, 10, 46.

20. Arun, M.; Asha, V.V. Preliminary studies on antihepatotoxic effect of Physalis peruviana (Solanaceae) against carbon tetrachloride-induced acute liver injury in rats. J. Ethnopharmacol. 2007, 111, 110-114. [CrossRef] [PubMed]

21. Wu, S.J.; Chang, S.P.; Lin, D.L.; Wang, S.S.; Hou, F.F.; Ng, L.T. Supercritical carbon dioxide extract of Physalis peruviana induced cell cycle arrest and apoptosis in human lung cancer H661 cells. Food Chem. Toxicol. 2009, 47, 1132-1138. [CrossRef] [PubMed]

22. Reddy, C.V.K.; Sreeramulu, D.; Raghunath, M. Antioxidant activity of fresh and dry fruit commonly consumed in India. Food Res. Int. 2010, 43, 285-288. [CrossRef]

23. Franco, L.A.; Matiz, G.E.; Calle, J.; Pinzón, R.; Ospina, L.F. Anti-inflammatory activity of extracts and fractions obtained from Physalis peruviana L. calyces. Biomedical 2007, 27, 110-115. [CrossRef]

24. Chauhan, A.S.; Sadia, G.A.; Ramesh, M.N.; Avula, R.Y.; Rekha, M.N.; Ramteke, R.S. Optimization of enzymatic liquefaction of Papaya (Carica papaya L.) and Jackfruit (Artocarpus heterophyllus Lam.) Pulp Using Response Surface Methodology. J. Food Agric. Environ. 2004, 2, 108-113.

25. Hunter, S. The Measurement of Appearance; John Wiley and Sons: New York, NY, USA, 1975; pp. $304-305$.

26. AOAC. Official Methods of Analysis, 16th ed.; Association of Official Analytical Chemists: Washington, DC, USA, 1995.

27. AOAC. Official Methods of Analysis, 15th ed.; Association of Official Analytical Chemists: Arungton, VA, USA, 1990.

28. Ranganna, S. Handbook of Analysis and Quality Control for Fruits and Vegetable Products, 3rd ed.; Tata McGraw-Hill Publishing Co. Ltd.: New Delhi, India, 1999; pp. 270-352.

29. Srivastava, R.P.; Kumar, S. Fruits and Vegetable Preservation, 2nd ed.; International Book Distributing Corporation: Lucknow, India, 1998; pp. 211-224.

30. Singleton, V.L.; Rossi, J.A. Colorimetry of total phenolics with phosphomolybdic- phosphotungstic acid reagents. Am. J Enol. Viticult. 1956, 16, 144-158.

31. APHA. Technical Committee on Microbiological Methods for Foods. In Compendium of Methods for the Microbiological Examination of Foods, 2nd ed.; Speck, M.L., Ed.; American Public Health Association: Washington, DC, USA, 1984; pp. 30-31.

32. Sindhumati, G.; Premalatha, M. Development and Storage Studies of Naturally Flavored Papaya-Pineapple Blended Ready-to-Serve (RTS) Beverages. Int. J. Sci. Res. 2013, 4, 856-860.

33. Maria, R.A.P.; Vivian, S.O.; Tatiana, C.P.; Sandra, H.P. Physicochemical stability, antioxidant activity and acceptance of beet and orange mixed juice during refrigerated storage. Beverages 2017, 3, 1-12.

34. Costa, G.M.; Silva, J.V.C.; Mingotti, J.D.; Barão, C.E.; Klososki, S.J.; Pimentel, T.C. Effect of ascorbic acid or oligofructose supplementation on L. paracasei viability, physicochemical characteristics and acceptance of probiotic orange juice. LWT Food Sci. Technol. 2017, 75, 195-201. [CrossRef]

35. Lalit, M.B.; Ahmad, T.; Senapati, A.K.; Pandit, P.S. Evaluation of Quality Attributes During Storage of Guava Nectar Cv. Lalit from Different Pulp and TSS Ratio. J. Process. Technol. 2014, 5, 1-5.

36. Pranjal, S.D.; Manjunatha, S.S.; Raju, P.S. Rheological behavior enzyme clarified sapota (Achras sapota L) juice at different concentration and temperatures. J. Food Sci. Technol. 2015, 52, 1896-1910.

37. Koffi, E.K.; Sims, C.A.; Bates, R.P. Viscosity reduction and prevention of browning in the preparation of clarified banana juice. J. Food Qual. 1991, 14, 209-218. [CrossRef] 
38. Girard, B.; Fukumoto, L.R. Apple juice clarification using microfiltration and ultrafiltration polymeric membranes. Food Sci. Technol. 1999, 32, 290-298. [CrossRef]

39. Saxena, D.; Chakraborty, S.K.; Sabikhi, L.; Singh, D. Process optimization for a nutritious low-calorie high-fiber whey-based ready-to-serve watermelon beverage. J. Food Sci. Technol. 2015, 52, 960-967. [CrossRef] [PubMed]

40. Kaul, R.K.; Gupta, N.; Sharma, I.; Gupta, V. Dietary fibers: A review. Beverage Food World 2009, 36, $23-27$.

41. Bhardwaj, R.L.; Mukherjee, S. Effects of fruit juice blending ratios on Kinnow juice preservation at ambient storage condition. Afr. J. Food Sci. 2011, 5, 281-286.

42. Yadav, R.; Tripathi, A.D.; Jha, A. Effect of storage time on the physicochemical properties and sensory attributes of Aloe vera ready-toserve (RTS) beverage. Int. J. Food Nutr. Public Health 2013, 6, 173-192.

43. Selvi, J.; Banumathi, P.; Kanchana, S.; Llama ran, M. Formulation of therapeutic drinks to boom human health (guava-lime-ginger RTS beverages). Food Sci. Res. J. 2013, 4, 141-146.

44. Ramachandran, P.; Nagarajan, S. Quality characteristics, nutraceutical profile, and storage stability of aloe gel-papaya functional beverage blend. Int. J. Food Sci. 2014, 1-7. [CrossRef] [PubMed]

45. Jakhar, M.S.; Pathak, S. Studies on the preparation and storage stability of blended ready-to-serve from ber (Zizyphus mauritiana lamk.) and Jamun (Syzygium cumini Skeels.) pulp. Plant Arch. 2012, 12, 533-536.

46. Lokesh, K.; Mishra, D.S. Quality attributes, phytochemical profile and storage stability studies of functional ready to serve (RTS) drink made from blend of Aloe vera, sweet lime, amla and ginger. J. Food Sci. Technol. 2017, 54, 761-769. [CrossRef]

47. Yadav, R.B.; Yadav, B.S.; Kalia, N. Development and storage studies on whey-based banana herbal (Mentha arvensis) Beverage. Am. J. Food Technol. 2010, 5, 121-129. [CrossRef]

48. Bhardwaj, R.L.; Pandey, S. Juice blends- A way of utilization of under-utilized fruits, vegetables, and spices. Food Sci. Nutr. 2011, 51, 563-570. [CrossRef] [PubMed]

49. Pawar, V.N.; Kardile, W.G.; Hashmi, S.I. Effect of heat processing on the discoloration of custard apple (Annona squamosa L.) fruit pulp and changes in quality characteristics during storage. Electron. J. Environ. Agric. Food Chem. 2011, 10, 2098-2113.

50. Nisar, R.; Baba, W.N.; Masoodi, F.A. Effect of chemical and thermal treatments on quality parameters and antioxidant activity of apple (pulp) grown in high Himalayan regions. Cogent Food Agric. 2015, 1, 1063797. [CrossRef]

51. Jadhav, S.B.; Joshi, S.D.; Garande, V.K. Studies on preparation and storage of raw and ripe kokum fruit products. J. Asian Hortic. 2006, 2, 205-207.

52. Nidhi, G.R.; Singh, R.; Rana, M.K. Changes in chemical composition of ready to serve bael guava blended beverages during storage. J. Food Sci. Technol. 2008, 45, 249-254.

53. Waskar, D.P.; Garande, V.K. Studies on blending of pomegranate and kokum juices. Beverages Food World 2003, 30, 27-28.

54. Gopalan, C.; Sastri, B.V.R.; Balasubramanian, S.C. Nutritive value of Indian Foods; National Institute of Nutrition, Council of Medical Research, Hyderabad, Indian Council of Medical Research: New Delhi, India, 1982; p. 204.

55. Kannan, S.; Thirumaran, A.S. Studies on the storage life of Jamun products. Indian Food Packer 2001, 55, $125-127$.

56. Sharma, M.; Gehlot, R.; Singh, R.; Siddiqui, S. Changes in chemical constituents and overall acceptability of guava jamun blend RTS drink and squash during storage. Beverage Food World 2012, 39, 39-42.

57. Tomás-Barberán, F.A.; Espín, J.C. Phenolic compounds and related enzymes as determinants of quality in fruits and vegetables. J. Sci. Food Agric. 2001, 81, 853-876. [CrossRef]

58. Cantwell, M.; Yang, S.F.; Rubatzky, V.; Lafuente, M.T. Isocoumarin content of carrots as influenced by ethylene concentration, storage temperature, and stress conditions. Acta Hortic. 1989, 258, 523-534.

59. Castro-López, C.; Sánchez-Alejo, E.J.; Saucedo-Pompa, S.; Rojas, R.; Aranda-Ruiz, J.; Martínez-Avila, G.C.G. Fluctuations in phenolic content, ascorbic acid and total carotenoids and antioxidant activity of fruit beverages during storage. Heliyon 2016, 2, e00152. [CrossRef] [PubMed]

60. Polshettiwar, S.A.; Ganjiwale, R.O.; Yeole, P.G.; Zamwar, S.P.; Wani, M.S. Studies on pesticide residue, heavy metal content and microbial count of some popular brands ofchywanprashsamples. Bioscan 2008, 3, 75-78.

(C) 2018 by the authors. Licensee MDPI, Basel, Switzerland. This article is an open access article distributed under the terms and conditions of the Creative Commons Attribution (CC BY) license (http:// creativecommons.org/licenses/by/4.0/). 